\title{
A COMPARATIVE STUDY ON MECHANICAL PROPERTIES OF SCC BY PARTIAL REPLACEMENT OF CEMENT WITH FLY ASH \& GGBS WITH THE USE OF GLASS FIBERS
}

\author{
Praveenkumar S R ${ }^{1}$, Manjunath K A ${ }^{2}$, G.Narayana ${ }^{3}$ \\ ${ }^{I}$ Persuing Master of Technology in Structural Engineering, Civil Engineering Department, S J C Institute of \\ Technology, Chickballapur, Karnataka, India \\ ${ }^{2}$ Assistant Professor, Civil Engineering Department, S J C Institute of Technology, Chickballapur, Karnataka, India \\ ${ }^{3}$ Professor \& Head of Civil Engineering Department, S J C Institute of Technology, Chickballapur, Karnataka, India
}

\begin{abstract}
Concrete is a versatile material that can be used for construction of all kinds or shapes of structural elements. Self Compacting Concrete (SCC) was developed by the Japan researchers in the year 1989. SCC is a special type of concrete that is competent or capable to flow and consolidate under its own weight without any segregation and bleeding between the reinforcing bars. SCC is one of the widely used types of concrete in the current world because it makes the work easier and it does not bleed at the joints of the moulds. In this work, an attempt has been made to prepare a high strength SCC of grade M60 by partially replacing the cement content with the untreated industrial byproducts like fly ash \& ground granulated blast furnace slag (GGBS) and also by replacing 100\% of natural sand with manufactured sand (M.Sand). With the use of these industrial byproducts, it results in an eco-friendly environment and also solves the problem of its disposal. The present work deals with the comparative study on mechanical properties like compressive strength, split tensile strength and flexural strength of SCC for various percentages of powder contents with the use of glass fibers at $0 \%, 0.1 \%$ \& $0.2 \%$ to the total volume of the concrete mix. In this study two types SCC mixes were prepared namely, Conventional SCC in which cement content was replaced by $30 \%$ with fly ash and Triple blended SCC in which cement content was reduced to $50 \%$ \& the rest of the cement content was replaced with fly ash \& GGBS by $25 \%$ each. The specimens are casted, cured \& tested for the required number of days.
\end{abstract}

Keywords: SCC, Fly Ash, GGBS, Glass Fiber \& Mix Design.

\section{INTRODUCTION}

The adaptability as well as use of concrete in construction engineering not required to be explained. Many investigations on Normal \& High Strength Concrete(HSC) are being carried out from past thirty years. According to IS456 - 2000 (Indian code for plain and RC structures), the strength of concretes ranging from $25 \mathrm{MPa}$ to $55 \mathrm{MPa}$ are called as standard concretes, while the strength of concretes above $55 \mathrm{MPa}$ to $120 \mathrm{MPa}$ known as HSC or high performance concrete(HPC). The strength of concretes above 120 or $150 \mathrm{MPa}$ are named as ultra - high performance concrete(UHPC). HSC comprise plentiful advantage all over the world in large edifice, dams, bridges \& buildings in violent environment. Usually, structure's components prepared by HPC will be closely reinforced. These types of dense reinforcements lead to severe harms during concrete placing. The heavy reinforced concrete troubles can be resolved by means of a concrete which is easy to place and can spread among the densely reinforced concrete structures.

In the recent years, self compacting concrete (SCC) has received large application for placing in densely reinforcement conditions with complicated placing circumstances. In favor of such uses, fresh concrete should have excessive fluidity \& better cohesiveness. SCC is a concrete, which will flow \& compacts by its self weight exclusive of segregation or bleeding. Normally, SCC has compressive strength in the range 60 to $100 \mathrm{~N} / \mathrm{mm}^{2}$. Although, lesser grades are to be determined and adopted depending on the obligation. At the time of 1980-90, the Japan researchers developed SCC for the very first time in university of Tokyo along with some of the top contractors in the industry. Since the durability of structures was fundamental concern in Japan, a sufficient compaction by experienced labors was crucial in seismic prone areas. As a result SCC was developed, which came into existence initially in 1989. Recently SCC was used for various applications in many of the countries for structural configurations which can offer superior operational surroundings with reduction of sound at the work. By using SCC, labor cost can be greatly reduced. SCC is a pioneering concrete which do not involve vibration for concreting. It is liable to compaction by its self load by filling the forms completely by achieving complete compaction in congested reinforcement which is homogenous and contains similar durable quality the same as conventional concrete.

In the production of SCC, a couple of varieties of SCC by various kinds of admixtures like fly ash, blast furnace slag, matakaolin \& silica fume have been tried. The mineral 
admixtures will be added to develop the distinct properties of concrete such as workability of concrete as well as sufficient compaction.

\section{MATERIALS USED}

\subsection{Cement}

Ordinary Portland Cement, (OPC) which is a 53 grade cement that confirms to Indian standard code IS:122691987 available in local market has been used in this study.

Table 1: Typical characteristics of cement

\begin{tabular}{|l|l|l|l|}
\hline $\begin{array}{l}\text { Sl. } \\
\text { no }\end{array}$ & $\begin{array}{l}\text { Tests Conducted } \\
\text { on Cement }\end{array}$ & Results & $\begin{array}{l}\text { Requirements as } \\
\text { per is 12269:2013 }\end{array}$ \\
\hline 1 & Normal Consistency & $32 \%$ & $28 \%-34 \%$ \\
\hline 2 & Initial setting time & $45 \mathrm{~min}$. & Not $<30 \mathrm{~min}$. \\
\hline 3 & Final setting time & $450 \mathrm{~min}$. & Not $>600 \mathrm{~min}$. \\
\hline 4 & Specific Gravity & 3.10 & $2.95-3.15$ \\
\hline
\end{tabular}

\subsection{Fly Ash}

Powdered fuel ash (PFA) is used as a secondary cementitious material, obtained from RMC plant of VNC Private limited, Hiranandani villas, Devanahalli, which confirms to the Indian code IS: 3812 Part $1 \& 2-2003$ and the tests are done for as per the guidelines of the code IS: $1727-1967$.

Table 2: Typical Properties of Fly Ash

\begin{tabular}{|l|l|l|l|}
\hline $\begin{array}{l}\text { Sl } \\
\text { no }\end{array}$ & Tests on fly ash & Result & $\begin{array}{l}\text { Permissible } \\
\text { Values }\end{array}$ \\
\hline 1 & Normal consistency & $44 \%$ & - \\
\hline 2 & Initial setting time & 35 min. & not $<30$ min. \\
\hline 3 & Final setting time & 500 min. & not $>600$ min. \\
\hline 4 & Specific gravity & 2.40 & $1.85-2.85$ \\
\hline 5 & Color & Brown & $\begin{array}{l}\text { grey \& brown } \\
\text { (tan) }\end{array}$ \\
\hline
\end{tabular}

\subsection{Ground Granulated Blast Furnace Slag (GGBS)}

GGBS also used as tertiary cementitious material which is obtained from Power Tech RMC Shetterahalli, Devanahalli Taluk, confirming to the Indian code IS: 12089 - 1987.

Table 3: Physical Qualities of GGBS

\begin{tabular}{|l|l|l|l|}
\hline $\begin{array}{l}\text { S1 } \\
\text { No }\end{array}$ & $\begin{array}{l}\text { Tests Conducted } \\
\text { on GGBS }\end{array}$ & Results & $\begin{array}{l}\text { Permissible } \\
\text { Values }\end{array}$ \\
\hline 1 & Normal Consistency. & $32 \%$ & - \\
\hline 2 & Specific Gravity & 2.90 & $2.85-2.95$ \\
\hline 3 & Color & White & \\
\hline
\end{tabular}

\subsection{Manufactured Sand (M.Sand)}

Due to the scarcity of natural sand, many research works are being carried out for alternate materials to use as fine aggregates. Manufactured sand (M.Sand) confirming to Indian code IS: 383 - 1970 (Zone II), obtained from Bharathi Mines and Rocks Products Pvt. Ltd., is employed as a fine aggregate in this work.

Table 4: Physical Properties of M.Sand

\begin{tabular}{|l|l|l|}
\hline $\begin{array}{l}\text { S1 } \\
\text { No }\end{array}$ & Tests Conducted On Fine Aggregate & Results \\
\hline 1 & Material Type & M.Sand \\
\hline 2 & Specific Gravity & 02.60 \\
\hline 3 & Absorption Of Water & $2.80 \%$ \\
\hline 4 & Fineness Modulus & 2.85 \\
\hline
\end{tabular}

\subsection{Coarse Aggregates}

The coarse aggregates of size $12.5 \mathrm{~mm}$ downsize are used in this work and it satisfies the specifications of IS: $383-$ 1970. The tests were conducted as per the Indian code IS: 2386 Part - I.

Table 5: Physical Properties of Coarse Aggregates.

\begin{tabular}{|l|l|l|}
\hline Sl. no & Tests conducted on CA & Result \\
\hline 1 & Specific Gravity & 2.54 \\
\hline 2 & Water Absorption $(\%)$ & 0.8 \\
\hline 3 & Loose Bulk Density $\left(\mathrm{Kg} / \mathrm{m}^{3}\right)$ & 1441.70 \\
\hline 4 & Compacted Bulk Density $\left(\mathrm{Kg} / \mathrm{m}^{3}\right)$ & 1574.47 \\
\hline
\end{tabular}

\subsection{Water}

Locally available potable water free all kinds of chemicals satisfying the requirements of Indian code IS: 456 - 2000 was used for preparing concrete.

\subsection{Chemical Admixture}

Admixtures are usually added to SCC to get good flowability and to make the concrete workable. To achieve high performance concrete, use of admixture is essential which will reduce the water-cement ratio. Hence the admixture used in this work is AURAMIX 300 PLUS provided from the FOSROC Pvt Ltd. The super-plasticizer is at a volume of $0.4 \%$ to total weight of the cementitious materials.

\subsection{Glass Fiber}

Glass fibers are used to improve the strength of the concrete by resisting the cracks that appear in the concrete. In this study glass fiber is added in $0 \%, 0.1 \% \& 0.2 \%$ to the full volume of the concrete mix. The typical properties of glass fiber are given in the table below. 
Table 6: Typical Properties of Glass Fiber

\begin{tabular}{|l|l|l|}
\hline S1 No & Property & Results \\
\hline 1 & Type of Glass Fiber & $\begin{array}{l}\text { AR-Glass Fiber } \\
\text { (Alkali Resistant) }\end{array}$ \\
\hline 2 & Color & White \\
\hline 3 & Length & $12 \mathrm{~mm}$ \\
\hline 4 & Diameter & $14 \mu$ \\
\hline
\end{tabular}

\section{MIX DESIGN}

A very simple and popular $\mathrm{Nan} \mathrm{Su}$ method is used to develop M60 grade SCC. In this study, two different types SCC mixes were developed one is the conventional SCC \& the other is the triple blended SCC. M60 grade mix quantities for both the mixes are given below.

\subsection{Conventional SCC (CSCC)}

Cement $=428.57 \mathrm{~kg} / \mathrm{m}^{3}$.

Fly Ash $=168.53 \mathrm{~kg} / \mathrm{m}^{3}$.

Fine Aggregate $=854.70 \mathrm{~kg} / \mathrm{m}^{3}$.

Coarse Aggregate $=681.203 \mathrm{~kg} / \mathrm{m}^{3}$.

Water $=214.956 \mathrm{~kg} / \mathrm{m}^{3}$.

Super plasticizer $=4 \mathrm{ml} / \mathrm{kg}$ of powder content.

\subsection{Triple Blended SCC (TBSCC)}

Cement $=428.57 \mathrm{~kg} / \mathrm{m}^{3}$.

Fly Ash $=92.21 \mathrm{~kg} / \mathrm{m}^{3}$.

GGBS $=92.21 \mathrm{~kg} / \mathrm{m}^{3}$.

Fine Aggregate $=854.70 \mathrm{~kg} / \mathrm{m}^{3}$.

Coarse Aggregate $=681.203 \mathrm{~kg} / \mathrm{m}^{3}$.

Water $=220.677 \mathrm{~kg} / \mathrm{m}^{3}$.

Super plasticizer $=4 \mathrm{ml} / \mathrm{kg}$ of powder content.

\section{WORKABILITY TESTS ON FRESH} CONCRETE

The self compacting concrete should exhibit the requirements specified in the EFNARC guidelines. Various types of workability tests are conducted on SCC in fresh state. In this study, Slump flow \& T50 test, V-funnel and Lbox tests are conducted to study the workability of SCC. The slump flow test is used to know the horizontal free flow of SCC without any kind of obstructions. The V-Funnel test is used to study the filling ability of concrete with a maximum size of coarse aggregates limiting to $20 \mathrm{~mm}$. LBox test is done to know the passing ability of SCC between the reinforcing bars and other obstructions without segregation or any kind of blocking. The test conducted on slump flow, V-funnel and L-box are shown in figures $1,2 \&$ 3 respectively.

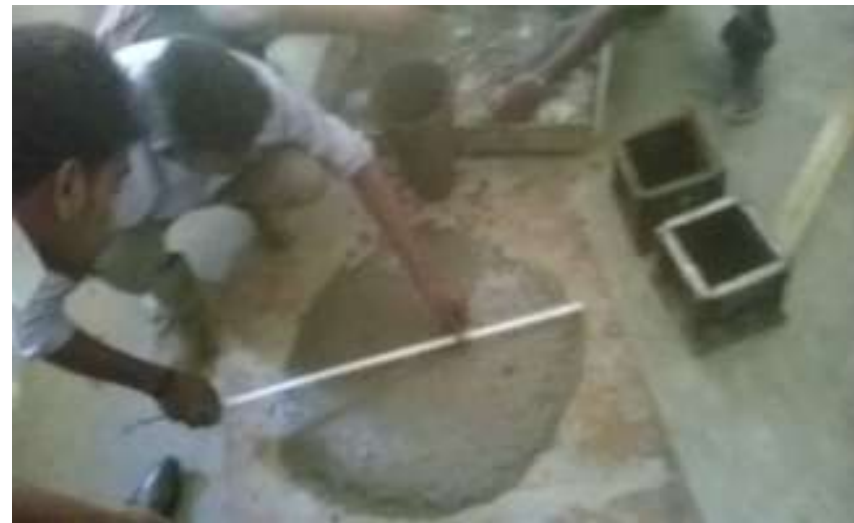

Fig 1: Slump flow test.

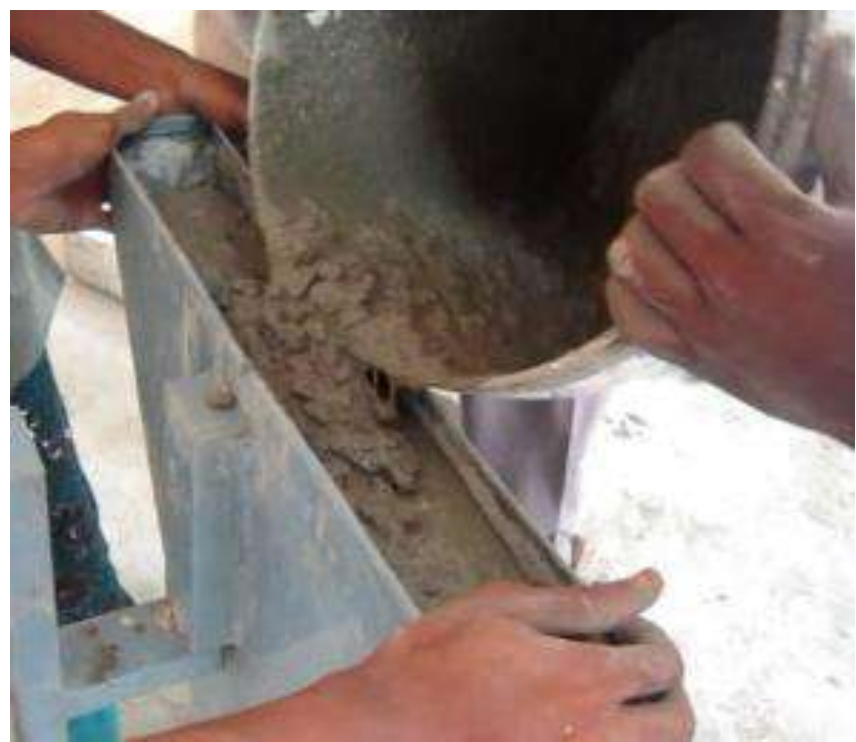

Fig 2: V-funnel test.

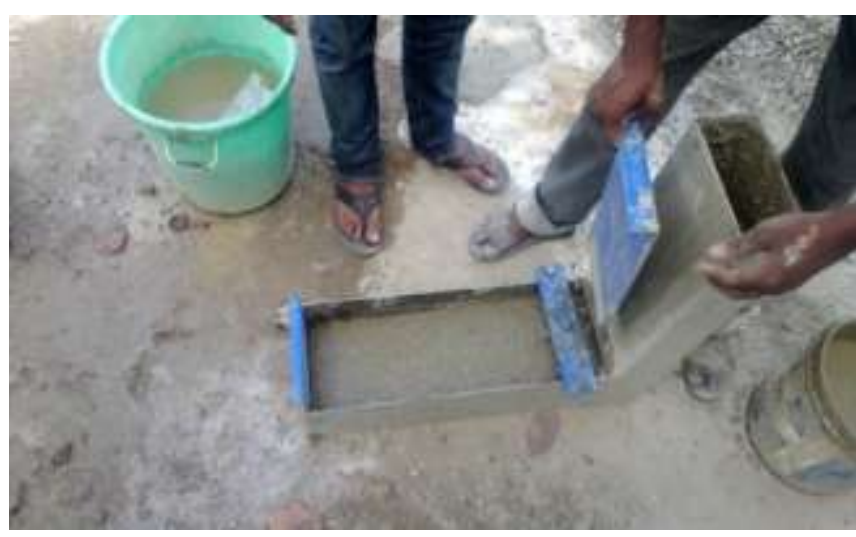

Fig 3: L-box test.

Table 7: Requirements of SCC as per EFNARC Guidelines

\begin{tabular}{|l|l|l|l|}
\hline $\begin{array}{l}\text { Sl } \\
\text { No }\end{array}$ & Properties & Unit & Permissible values \\
\hline 1 & Slump flow & $\mathrm{mm}$ & $650-800$ \\
\hline 2 & $\mathrm{~T}_{50}$ Slump flow & $\mathrm{sec}$ & $2-5$ \\
\hline 3 & V-Funnel & $\mathrm{sec}$ & $8-12$ \\
\hline 4 & L-Box & - & $0.8-1$ \\
\hline
\end{tabular}


Table 8: Workability Test Results

\begin{tabular}{|l|l|l|l|l|l|}
\hline $\begin{array}{l}\text { Sl } \\
\text { No }\end{array}$ & $\begin{array}{l}\text { Type of } \\
\text { Mix }\end{array}$ & $\begin{array}{l}\text { Slump } \\
\text { Flow } \\
(\mathbf{m m})\end{array}$ & $\begin{array}{l}\mathbf{T}_{\mathbf{5 0}} \\
\text { test } \\
(\mathbf{s e c})\end{array}$ & $\begin{array}{l}\text { V } \\
\text { funnel } \\
(\mathbf{s e c})\end{array}$ & $\begin{array}{l}\text { L-box }= \\
(\mathbf{h} 2 / \mathbf{h 1})\end{array}$ \\
\hline 1 & CSCC & 680 & 5 & 11 & 0.9 \\
\hline 2 & TBSCC & 685 & 4 & 10 & 1.0 \\
\hline
\end{tabular}

\section{TESTS ON HARDENED CONCRETE}

\subsection{Compressive Strength Test}

The cubes of size $150 \mathrm{~mm} * 150 \mathrm{~mm} * 150 \mathrm{~mm}$ were casted and cured for a period of $7,28 \& 56$ days for all the mixes. Three cube samples were tested in the compressive testing machine to get the average compressive strength of each mix. The test results are given table 9 .

Table 9: Compressive Strength of SCC

\begin{tabular}{|l|l|l|l|l|}
\hline \multirow{2}{*}{$\begin{array}{l}\text { SI } \\
\text { No }\end{array}$} & \multirow{2}{*}{ TYPE OF MIX } & \multicolumn{3}{|l|}{$\begin{array}{l}\text { Compressive Strength } \\
\text { (MPa) }\end{array}$} \\
\cline { 3 - 5 } & & $\begin{array}{l}7 \\
\text { Days }\end{array}$ & $\begin{array}{l}28 \\
\text { Days }\end{array}$ & $\begin{array}{l}56 \\
\text { Days }\end{array}$ \\
\hline 1 & CSCC 0\% GF & 36.44 & 59.11 & 64.45 \\
\hline 2 & CSCC 0.1\% GF & 40.89 & 61.78 & 68.45 \\
\hline 3 & CSCC 0.2\% GF & 38.22 & 60.89 & 66.67 \\
\hline 4 & TBCSCC 0\% GF & 35.11 & 57.78 & 65.33 \\
\hline 5 & TBCSCC 0.1\% GF & 37.78 & 59.56 & 70.22 \\
\hline 6 & TBCSCC 0.2\% GF & 36.88 & 58.67 & 67.11 \\
\hline
\end{tabular}

\subsection{Split Tensile Strength Test}

The cylinders of size $150 \mathrm{~mm}$ dia and $300 \mathrm{~mm}$ height were casted and cured for a period of 7, $28 \& 56$ days for all the mixes. Three cylinder samples were tested in the compressive testing machine to get the average split tensile strength of each mix.

Table 10: Split Tensile Strength of SCC

\begin{tabular}{|l|l|l|l|l|}
\hline \multirow{2}{*}{$\begin{array}{l}\text { Sl } \\
\text { No }\end{array}$} & \multirow{2}{*}{ TYPE OF MIX } & \multicolumn{3}{|l|}{$\begin{array}{l}\text { Split Tensile Strength } \\
\text { (MPa) }\end{array}$} \\
\cline { 3 - 5 } & & $\begin{array}{l}7 \\
\text { Days }\end{array}$ & $\begin{array}{l}28 \\
\text { Days }\end{array}$ & 56 Days \\
\hline 1 & CSCC 0\% GF & 2.90 & 4.98 & 5.41 \\
\hline 2 & CSCC 0.1\% GF & 3.19 & 5.67 & 6.10 \\
\hline 3 & CSCC 0.2\% GF & 2.98 & 5.41 & 5.70 \\
\hline 4 & TBCSCC 0\% GF & 2.70 & 4.84 & 5.69 \\
\hline 5 & TBCSCC 0.1\% GF & 2.95 & 5.55 & 6.41 \\
\hline 6 & TBCSCC 0.2\% GF & 2.77 & 5.29 & 5.98 \\
\hline
\end{tabular}

\subsection{Flexural Strength Test}

The beams of size $2000 \mathrm{~mm} * 250 \mathrm{~mm} * 150 \mathrm{~mm}$ were casted and cured for a period of 28 days for all the mixes. The beam samples were tested in the loading frame to get the average ultimate load of each mix.
Table 11: Flexural behavior of RC Beams

\begin{tabular}{|l|l|l|l|}
\hline \multirow{2}{*}{ MIX TYPE } & \multicolumn{2}{|l|}{ Load (KN) } & Ultimate \\
\cline { 2 - 3 } & $\begin{array}{l}\text { First } \\
\text { Crack }\end{array}$ & $\begin{array}{l}\text { Second } \\
\text { Crack }\end{array}$ & load (KN) \\
\hline CSCC 0\% GF & 125 & 131 & 160 \\
\hline CSCC 0.1\% GF & 127 & 150 & 193 \\
\hline CSCC 0.2\% GF & 129 & 152 & 171 \\
\hline TBSCC 0\% GF & 122 & 154 & 185 \\
\hline TBSCC 0.1\% GF & 131 & 173 & 219 \\
\hline TBSCC 0.2\% GF & 130 & 170 & 204 \\
\hline
\end{tabular}

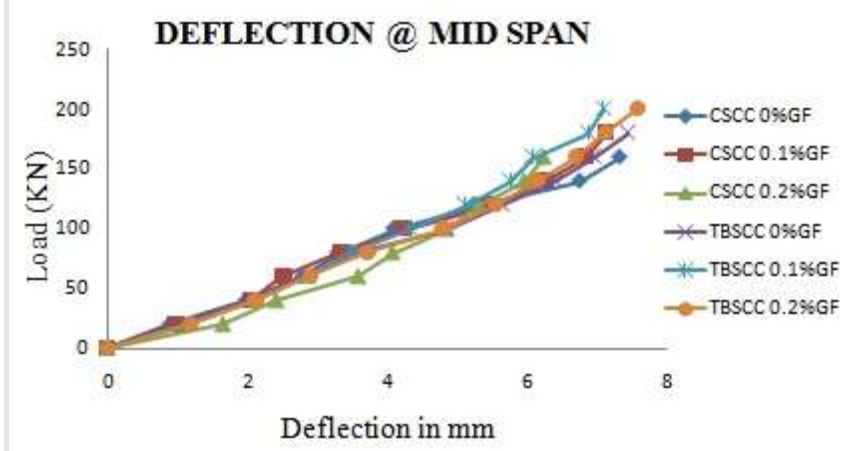

Graph 1: Load vs Deflection@ mid span

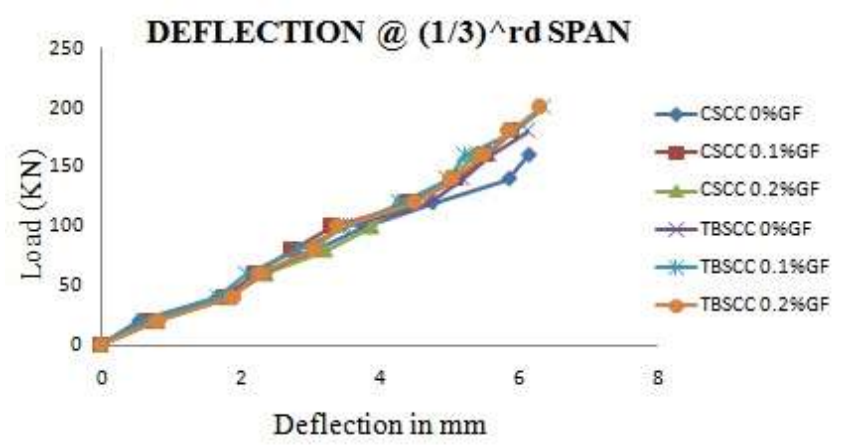

Graph 2: Load vs Deflecction @ (1/3) $)^{\text {rd }}$ Span

\section{CONCLUSION}

From the obtained test results, the following conclusions were made.

1. The triple blended SCC exhibits good workability properties compared to conventional SCC. This is due to the higher content of finer particles such as fly ash \& GGBS along with cement.

2. From the flexural test results of reinforced concrete beams, it can be concluded that the load carrying capacity of triple blended SCC is more than that of conventional SCC.

3. Also, it can be concluded that manufactured sand can be used as a alternate material for river sand.

4. The results of compressive strength, split tensile strength \& flexural strength exhibits the optimum dosage of glass fiber that can be used is $0.1 \%$ to the total volume of the mix. 
5. Finally from this experimental work, it may be concluded that the use of industrial by-products such as fly ash \& GGBS has vast advantage making the environment eco-friendly.

\section{SCOPE FOR FUTURE STUDY}

1. To study the mechanical properties of high strength SCC using other alternate cementitious materials at different percentages.

2. Use of various types of fibers to determine the performance of SCC for various proportion of addition.

3. Study the mechanical properties of SCC for higher grade of concrete.

4. To study the behavior of reinforced SCC of beams under various loading conditions

\section{ACKNOWLEDGEMENT}

I am very much thankful Mr. Manjunath $\mathrm{K}$ A and Dr.G.Narayana for their continuous guidance \& support. I would also thank civil engineering department, S.J.C. Institute of Technology, Chickballapur. Also, last but not the least I would like to thank my parents \& friends for their continuous support for the completion of this experimental work.

\section{REFERENCES}

[1] Nan Su, Kung-Chung Hsu, and His-Wen Chai, "A simple mix design method for self-compacting concrete". Cement and Concrete Research 31 (2001) $1799-1807$.

[2] Shahana Sheril P.T, "Self Compacting Concrete using Fly Ash and Glass Fiber". International journal of engineering research and technology (IJERT), ISSN: 2278-0181, Vol.2, Issue 9, September - 2013.

[3] K.V.Pratap, M.Bhasker and P.S.S.R.Teja, "Triple Bending of Cement Concrete with Fly Ash and Ground Granulated Blast Furnace Slag”. IJEAR Vol. 4, Issue Spl-2, Jan - July 2014.

[4] C. Pramukh ganapathy, "Experimental Study on Self Compacting Concrete Containing Industrial ByProducts". European scientific journal, April 2014 edition, Vol.10, No.12 ISSN: $1857-7881$.

[5] J. Keerthana, "A Comparative Study on SCC of Partial Replacement with Quarry Rock Dust, with and without Glass Fibers". International journal of innovative technology and research, Volume no.2, Issue No.6, October-November 2014, 1621 - 1626.

[6] Rita M. Rathod \& M. R. Vywahare, "The Effect of Varying Proportions of Fly Ash and Silica Fume on Fresh and Mechanical Properties of High Strength Self Compacting Concrete". International journal of innovative technology and research, Volume No.2, Issue 7, july 2015.

[7] Rita M. Rathod and M.R.Vyawahare, "To Study the Effect of Varying Proportion of Fly Ash and Silica Fume on Sorptivity of High Strength Self Compacting Concrete". International journal of engineering and innovative technology (IJEIT), Volume 5, Issue 1, July 2015.
[8] Ravi Shankar Yadav, "To Study the Properties of SCC using Recycled Aggregates and Glass Fiber". International Journal of Recent Research in Civil and Mechanical Engineering (IJRRCME) Volume 2, Issue 1, pp: (187-191), April 2015 - September 2015.

[9] Asha Deepthi. Deva "A Comparative Study on Mechanical Properties of Normal Vibrated Concrete (NVC) \& Self-Compacting Concrete (SCC)". International Journal of Civil and Structural Engineering Research, Volume 2, Issue 2, pp: (93-100), October 2014 - March 2015.

[10] Pradeepa, "An Experimental Study on Properties of Fiber Reinforced Self-Compacting Concrete", ISSN: 2348 - 8352, National Conference on Research Advances in Communication, Computation, Electrical Science and Structures (NCRACCESS-2015).

[11] M.S.Shetty, a text book of "Concrete Technology Theory and Practice", multicolor illustrative revised edition, S.CHAND PUBLISHING, A division of S.Chand \& Company limited.

\section{BIOGRAPHIES}

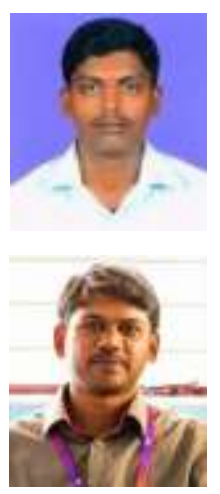

Mr. PRAVEenKuMAR S R, Pursuing M.Tech in Structural Engineering in S.J.C. Institute of Technology, Chickballapur.

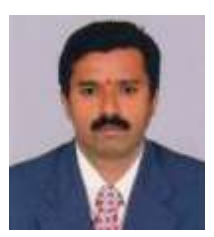

Mr. MANJUNATH K A, Assistant Professor, Department of Civil Engineering, S.J.C. Institute of Technology, Chickballapur. He has wide range of knowledge in Structural Engineering with 5 years of experience as Assistant Professor.

Dr. G.NARAYANA, Professor and Head, Department of Civil Engineering, S.J.C Institute of Technology, Chickballapur. He has wide range of knowledge \& experience in teaching as well as researches in Structural Engineering field. He is also a Structural Designer and Consultant for many Projects. 